\title{
A Simple Laboratory Method for Benthal Oxygen Demand
}

\author{
D.J. Douglas 1
}

S. O'Brien!

Keywords : Estuary, B.O.D., Sediment Oxygen Demand, Benthal Demand.

A simple laboratory method for determining Benthal Oxygen Demand is described. Results of experiments carried out on the Castletown Estuary are given. The Benthal Demand Index is calculated for all stations in the Castletown Estuary to determine the relative effect of Sediment Oxygen Demand from the anoxic muds and Biochemical Oxygen Demand from organic matter in suspension.

Une simple méthode de laboratoire pour la Demande Benthique en Oxygène.

Mots clés: Estuaire, B.O.D., Demande d'Oxygène du Sédiment, Demande Benthique.

Une simple méthude de laboratoire pour déterminer la Demande Benthique en Oxygène est décrite.

Un indice de Demande Benthique est calculé pour plusicurs stations dans l'estuaire Castletown (Irlande) pour déterminer l'importance relative de la Demande d'Oxygène du Sédiment à partir des vases anoxiques et de la Demande Biochimique en Oxygène à partir de la matière organique en suspension.

\section{Introduction}

The measurement of oxygen consumption (Benthal Demand) by sediments in rivers and lakes can provide an indication of the rate at which organic matter, which settles on the bottom, is remineralised. The mineralisation process affects oxygen in the overlying water in two ways :

(1) by removing dissolved oxygen to satisfy the respiratory requirements of aerobic bacteria and

(2) depletion of dissolved oxygen to satisfy the immediate oxygen demand of reduced substances in the sediments.

In stratified lakes oxygen depletion in the hypolimnion may be a direct result of Sediment Oxygen Demand (S.O.D.). Lucas \& Thomas (1971) have shown that it is the primary cause of deoxygenation in Lake Erie. In rivers and lakes receiving a high B.O.D. loading from organic effluents total oxygen depletion may result - particularly if the B.O.D. is combined with a high S.O.D. Shallow rivers and lakes are

1. Dept. of Experimental Sciences, Regional Technical College, Dundalk, Co. Louth, Ireland. particularly vulnerable in this respect. Most experimental methods in current use measure either the oxygen demand of the water (B.O.D.) or the oxygen demand of the sediment (S.O.D.). The Benthal Demand (B.D.) in rivers and lakes is, however, a combination of these processes. The potential demands on dissolved oxygen can only be determined if all processes are considered. Measurements of this type depend on the integrity of the sediment profile being maintained, particularly that of the microzone at the mud/water interface. This can only achieved if undisturbed vertical cores which include the overlying water are obtained. Grab samples destroy the mud water interface and mixed samples destroy the sedimentary profile which has built up over a number of years.

\section{Experimental Apparatus}

Plexiglass cores $(60 \mathrm{~cm}$ long, $3 \mathrm{~cm}$ diameter $)$ of sediment are clamped to a retort stand and an external thermostatically controlled heating coil is wrapped around the outside of the core. The hot water heating coil is maintained at a constant temperature of $20^{\circ} \mathrm{C}$. The water overlying the core is saturated 


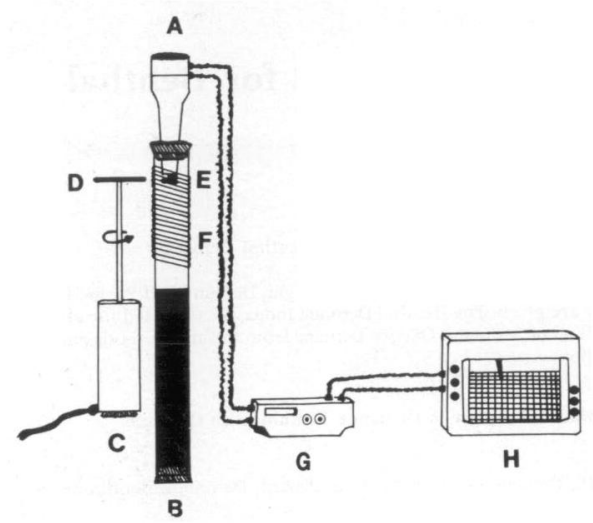

Fig. 1 : Experimental apparatus. (A) Oxygen electrode (B) Core inside transparent core tube (C) Electric motor (D) External magnet (E) internal stirring magnet (F) Thermostatically controlled hot water heating coil (G) pH meter (H) Chart recorder.

with oxygen using a small aquarium pump, care being taken to prevent disturbance of the sediment. During aeration turbulence is reduced to a minimum by means of a diffuser.

Once the water is fully oxygenated an Orion $\mathbf{O}_{2}$ electrode (model 97-08) mounted in a rubber bung is inserted in the top of the tube. No gap should exist between the water surface and the bottom of the stopper. The oxygen electrode is linked to a digital pH meter which in turn connects to a chart recorder. The water above the sediment is kept in circulation by means of a small stirring magnet attached to the base of the probe. This is driven by an induced field set up by a motor driven external magnet. Stirring speed is adjusted to prevent disturbance of the sediment at the mud water interface. Mixing prevents microstratification during oxygen consumption and maintains a constant flow over the oxygen electrode. Experiments are carried out in the dark to eliminate the effects of photosynthesis. The complete experimental apparatus is shown (fig. 1).

\section{Sampling Procedure}

Twenty six undisturbed sediment cores together with at least $20 \mathrm{~cm}$ depth of overlying water were collected from the mesohaline region of the
Castletown Estuary Dundalk, Co. Louth (fig. 2). Cores were taken over a one year period (18-2-1983 to 28-2-1984). Thirteen stations were selected each station being sampled, during low tide conditions, on two occasions i.e. Winter/Spring (Period I) and Summer/Autumn (Period II). Because of limited equipment only one core could be taken each time.

Cores were kept vertical and were returned to the laboratory within approximately fifteen minutes of sampling. Oxygen depletion was measured over a maximum period of 24 hours by which time a detectable change ( $>25 \%$ ) was obvious. In some cases the water was totally depleted of oxygen within six hours. Benthal Demand is calculated on the basis of the surface area of the mud in the core, the volume of water overlying the sediment, the degree of oxygen depletion and the time in days. Results are expressed as g of oxygen consumed per square metre of sediment surface per day. This value incor. porates both the B.O.D. of the water and the S.O.D.

\section{Results and Discussion}

Benthal Oxygen Demand for each station is given (Table 1). The average rate for all stations throughout the study period was $2.274 \mathrm{~g} \mathrm{O}_{2} / \mathrm{m}^{2} /$ Day. These results are fairly high when compared with those 


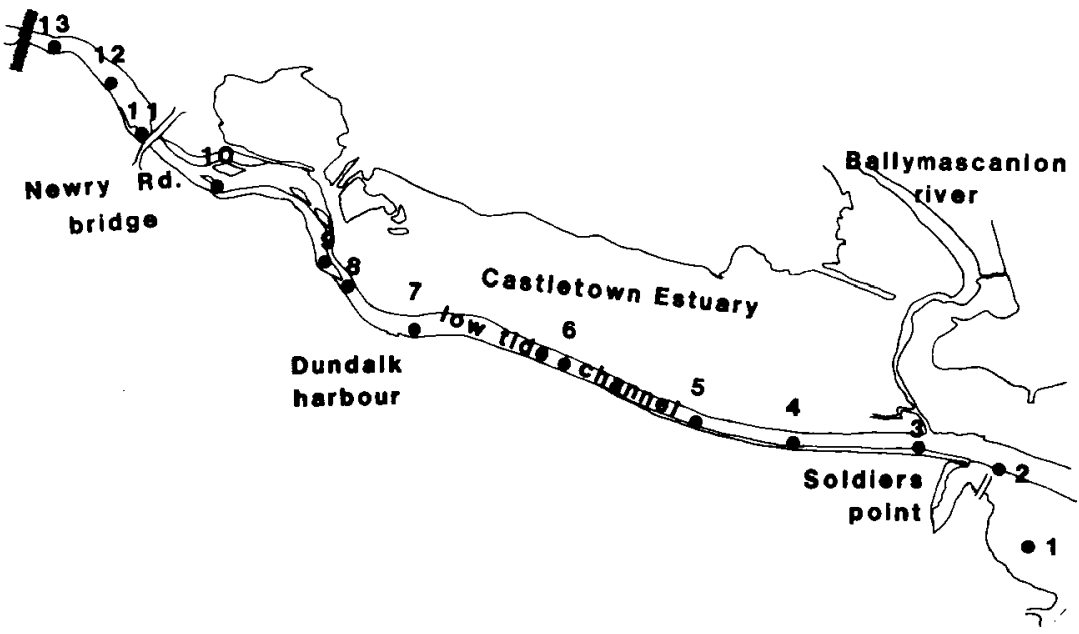

Fig. 2 : Location of sampling sites in the Castletown Estuary. Co. Louth, Ireland (Note : during the low tide the salinity at Soldiers Point is less than $1.0 \%$ and gets progressively lower as the Newry Road Bridge is approached-falling to $0.1 \% 0$ ).

Table 1: Benthal Demand $\left(\mathrm{g} / \mathrm{O}_{2} / \mathbf{m}^{2} / \mathrm{Day}\right)$ Period 1 - January to April 1983 Period 2 - July to October 1983

$\begin{array}{ccc}\text { CORE SITE } & \text { PERIOD 1 } & \text { PERIOD 2 } \\ \mathbf{1} & \mathbf{2 . 2 3 2} & 1.750 \\ 2 & 2.022 & 2.021 \\ 3 & 1.925 & 7.311 \\ \mathbf{4} & 1.851 & 3.561 \\ \mathbf{5} & 1.295 & 1.410 \\ 6 & 1.598 & 1.523 \\ 7 & 2.388 & 0.970 \\ \mathbf{8} & 1.737 & 3.709 \\ 9 & 1.019 & 6.828 \\ \mathbf{1 0} & 1.435 & 1.205 \\ \mathbf{1 1} & 1.555 & 1.919 \\ \mathbf{1 2} & 1.957 & 2.339 \\ \mathbf{1 3} & 1.940 & 1.626\end{array}$

obtained by Lucas and Thomas (op.cit.) who recorded an average of $1.6 \mathrm{~g} \mathrm{O}_{2} / \mathrm{m}^{2} /$ Day. Their experiments were carried out in situ and took place at lower temperatures $\left(9-13.7^{\circ} \mathrm{C}\right)$ than was the case with our experiments $\left(20^{\circ} \mathrm{C}\right)$. If allowance is made for this difference in temperature then the results are comparable. It is important to note that Lucas and Thomas discounted the significance of B.O.D. and C.O.D. in their results because they were dealing with hypolimnetic waters where settlement was rapid and currents reduced. Results of Fillos \& Swanson (1975) for the Muddy River yielded S.O.D. values of $1.872 \mathrm{~g} \mathrm{O}_{2} / \mathrm{m}^{2} / \mathrm{Day}$ at $20^{\circ} \mathrm{C}$ and $2.712 \mathrm{~g}$ $\mathrm{O}_{2} / \mathrm{m}^{2} / \mathrm{Day}$ at $24^{\circ} \mathrm{C}$. The temperature dependency of the tests suggests that temperature controlled laboratory measurements provide a more consistent estimate of deoxygenating potential than would in situ tests. By controlling the water supply to their reaction vessels Fillos and Swanson (op.cit.) were able to ignore B.O.D. and C.O.D. but the fact that they worked with mixed samples probably resulted in elevated results due to the destruction of the natural sedimentary profile. Re-suspension of sediments 
in natural systems can increase oxygen demand by a factor as high as ten (Lucas \& Thomas, op.cit.).

The measurement of Benthal Demand should be regarded in the same light as the measurement of B.O.D. It cannot reflect exactly what is happening in the natural environment because of the rigidly controlled experimental conditions. However, it does give an estimate of the potential deoxygenating effects of sediment and overlying water, if reaeration were prevented, and therefore is of more use than B.O.D. or C.O.D. alone.

Measurement of Benthal Demand can show both temporal and spatial variation. Smith \& al (1983) have indicated that cores taken within $1 \mathrm{~m}$ of each other from the North Pacific show considerable variation in oxygen consumption. This type of variation was also demonstrated by Hinga \& al (1979). Examination of the present results, particularly for adjacent stations, confirms this variation for estuarine waters and probably reflects the variation in build up in organic matter at different stations.

Temporal variation in oxygen consumption rates is also common. This tends to occur at more eutrophic stations and is nearly always a result of increased organic matter, either from waste discharge or primary production, in the surface waters.

In the Castletown Estuary large scale variation was obvious at five stations $-3,4,7,8$ and 9 . One of these (7) had its highest value in February and decreased considerably by October. This station received intermittent discharges from an adjacent slaughterhouse, which may go some way towards explaining this atypical result. The other four stations all showed an increase in Benthal Demand in the second half of the year. As temperature was kept constant throughout the tests it would seem that the increase was due to increased organic matter at these stations. This portion of the estuary receives the bulk of sewage discharges from Dundalk town and during dry weather is subject to very low fresh. water flows, mainly as a result of water abstraction upstream.

In order to assess the relative effect of the B.O.D. of the water and the S.O.D., the rate constant $k_{1}$ for B.O.D. was determined experimentally for a number of stations in the estuary.

Results show that $40 \%$ to $55 \%$ of the total B.O.D. is generated in the first 24 hours and of this some $80 \%$ occurs in the first six hours (i.e. up to $44 \%$ of
Table 2 : B.D., B.O.D. and B.D.I, results for Period 2 (July to October 1983).

$\begin{array}{cccc}\text { Core site } & \begin{array}{c}\text { Benthal Demand } \\ \left(\mathrm{g} \mathrm{O}_{2} / \mathrm{m}^{2} / \text { Day }\right)\end{array} & \begin{array}{c}\text { B.O.D. } \\ \mathrm{mg} / \mathrm{L} / \mathrm{O}_{2} / \text { Day }\end{array} & \text { B.D.I } \\ 1 & 1.750 & 11.6 & 99 \\ 2 & 2.021 & 11.6 & 6.69 \\ 3 & 7.311 & 4.3 & 0.36 \\ 4 & 3.561 & 5.1 & 0.59 \\ 5 & 1.410 & 5.1 & 0.82 \\ 6 & 1.523 & 13.0 & 999 \\ 7 & 0.970 & 2.5 & 0.43 \\ 8 & 3.709 & 3.3 & 0.32 \\ 9 & 6.828 & 3.3 & 0.20 \\ 10 & 1.205 & 7.3 & 2.33 \\ 11 & 1.919 & 5.1 & 4.00 \\ 12 & 2.339 & 4.9 & 0.47 \\ 13 & 1.626 & 4.9 & 0.59\end{array}$

the total B.O. $D_{5}$ ). This has important environmental, significance particularly when the B.O.D. of the water is high.

Taking the higher figure for B.O.D. in the first 24 hours (i.e. $55 \%$ of B.O.D 5 ) it is possible to calculate the contribution of B.O.D. to the benthal demands. Results which are only available for Period II are given (Table II). There appears to be competition between the water and the sediment for the available oxygen. Where the B.O.D. of the water was greater than $6 \mathrm{mg} \mathrm{t}^{-1}$ deoxygenation occurred mainly to satisfy this demand - at lower B.O.D. values S.O.D. prevailed.

In order to assess the relative demands of both B.O.D. and S.O.D. the Benthal Demand Index was calculated as follows :

$$
\text { B.D.I. }=\frac{p}{100-p}
$$

(where $p$ is the B.O.D. expressed as a percentage of B.D. in $\mathrm{mg} / \mathrm{L} / \mathrm{O}^{2} /$ Day)

B.D.I's greater than unity indicate the predominance of B.O.D., while B.D.I's less than unity indicate the predominance of S.O.D.

The highest Benthal Demands (found at stations $3,4,8$ and 9) occur where S.O.D. prevails. However, it is likely that increased B.O.D. (24 hours) would change this in favour of B.O.D. These regions of the estuary are subject to heavy discharges of organic wastes, much of which settles out on the bottom in the vicinity of these stations. 


\section{References}

Fillos (J.) \& Swanson (W.R.). 1975. - The release rate of nutrients from river and lake sediments. Jour. Water Poll. Control Fed., $47 ; 1032-1042$.

Hinga (K.R.), Sieburth (J.) \& Heath (G.R.). 1979. — The supply and use of organic material at the deep-sea floor. I. Mar. Res., 37 : 557-579.
Lucas (A.M.) \& Thomas (N.A.). 1971, - Sediment Oxygen Demand in Lake Erie's Central Basin 1970. Proc. 14th Conf. Great Lakes Res. 1971 : 781-787. Internat. Assoc. Great Lakes Res. Smith (K.L.), Laver (M.B.) \& Brown (N.O.) 1983. - Sediment cornmunity oxygen consumption and nutrient exchange in the central and eastern North Pacific. Limnol. Oceanogr. 28 (5) : 882-898. 